sien durchgeführt. Hierzu wurden $300 \mathrm{mg}$ reine Rickettsien aus Melolontha spec. in $5 \mathrm{ml}$ des Antiserums gegeben. Das Gemisch wurde unter Schütteln $6 \mathrm{~h}$ bei $38^{\circ} \mathrm{C}$ und $20 \mathrm{~h}$ bei $4^{\circ} \mathrm{C}$ gehalten, dann wurden die Rickettsien vom Serum scharf abzentrifugiert. Das überstehende nunmehr gegen die Maikäfer-Rickettsien abgesättigte Serum wurde gegen die verschiedenen Rickettsien-Stämme austitriert: Während das Serum nicht mehr mit MaikäferRickettsien zu reagieren vermochte, wurden die Tipula-Rickettsien bis zu einem Titer von $1: 250$ und die Popillia-Rickettsien bis zu 1:25 agglutiniert. Aus den serologischen Daten ist zu schließen, daß die drei genannten Rickettsien ein gruppenspezifisches Teilantigen und außerdem je ein artspezifisches Teilantigen besitzen.

Zur Absättigung von Anti-R. tipulae-Serum durch Rickettsien aus Popillia japonica stand leider nicht genügend Antigen zur Verfügung, desgleichen waren nicht genügend Tipula-Rickettsien zur Absättigung des Anti- $R$. melolonthae-Serums vorhanden. Trotzdem ergibt sich aus diesen serologischen Untersuchungen, $\mathrm{da} ß$ es sich bei den drei zur Diskussion stehenden Rickettsien offenbar um drei verschiedene Serotypen (Arten) der Gattung Rickettsiella handelt, die sich morphologisch jedoch kaum unterscheiden.

Herrn Dr. S. R. Dutky, US. Dept. of Agric. Insect Pathology, Station Beltsville, Maryland, danke ich für die Überlassung der rickettsien-kranken Engerlinge von Popillia japonica und Herrn Dr. Müller-Kögler, Biol. Bundesanstalt, Darmstadt, für die Überlassung von rickettsien-kranken Larven von Tipula paludosa. Die EM-Aufnahmen wurden durch das freundliche Entgegenkommen von Herrn Prof. Dr. U. Hofmans, Eduard-Zintl-Institut der TH Darmstadt, und durch die Gastfreundschaft der Fa. Carl Zeiß, Abteilung für Elektronenmikroskopie, ermöglicht.

Durchgeführt mit Unterstützung der De u t s chen Forschungsgemeinschaft.

\section{Potentiometric Studies on Mercury molybdate}

\author{
By C. M. Gupta and Ram Sahai Saxena \\ Chemical laboratories, Government College, \\ Kota (Rajasthan) \\ (Z. Naturforschg. 13 b, 557-559 [1958] ; eingeg. am 19. Mai 1958)
}

The formation of mercury (ic) molybdate has been studied from E.M.F. measurements involving potentiometric titrations between $\mathrm{Na}_{2} \mathrm{MoO}_{4}$ solution $\left(p_{\mathrm{H}}=7.2\right.$ to 7.3$)$ and $\mathrm{Hg}\left(\mathrm{NO}_{3}\right)_{2}\left(p_{\mathrm{H}}=1.4\right.$ to 2.0$)$ using platinum as indicator electrode, with either of the reactants alternatively used as the titrant. A marked change in E.M.F. is obtained at the equivalence point corresponding to the formation of insoluble normal mercury molybdate having the composition $\mathrm{HgO} \cdot \mathrm{MoO}_{3}$.

A survey of literature reveals that there are meagre references on the study of mercury molybdate. A few investigators have only prepared mercury molybdate. According to $\mathrm{H}_{\text {Irzel }}{ }^{1}$, finely divided $\mathrm{HgO}$ is rapidly attacked by a concentrated solution of acid ammonium molybdate and after boiling for some time, a yellowish white granular precipitate is formed. The composition of the precipitate was not determined.

Molybdate ion exists in different state of aggregation depending on $p_{\mathrm{H}}$ of the solution. This has been esta-

1 C. H. Hinzer, Liebigs Ann. Chem. 84, 267 [1852].

2 G. JANDer u. Mitarbb., Ber. dtsch. chem. Ges. 194, 383 [1930]. blished by $\mathrm{JANDER}^{2}$ and his collaborators and other workers. It is of interest, therefore, to study the conditions, favourable for the precipitation of mercury molybdate by applying electro-metric methods.

'Analar' (B.D.H.) chemicals were used. $\mathrm{Na}_{2} \mathrm{MoO}_{4}$ solution was estimated as $\mathrm{MoS}_{3} \cdot 2 \mathrm{H}_{2} \mathrm{O}$ (Analytica chimica Acta 9, 263 [1953]) and $\mathrm{Hg}\left(\mathrm{NO}_{3}\right)_{2}$ was prepared in minimum amount of dil $\mathrm{HNO}_{3}$ and was estimated as $\mathrm{Hg}(\mathrm{CNS})_{2}$ by titrating against $\mathrm{KCNS}$ which was standardised by A.R. $\mathrm{AgNO}_{3}$ (Vogel, 'A Text Book of quantitative analysis', page $265-266)$.

\section{Potentiometric Procedure}

For measurement of E.M.F. Cambridge $p_{\mathrm{H}}$ meter was used. A bright platinum wire was used as indicator electrode in conjunction with saturated calomel electrode. Titrations were done in aqueous and aqueous alcoholic solutions. Titrations in presence of alcohol were done up to a total concentration of $20 \%$ by volume. The curves were plotted between the volume of titrant and the E.M.F. observed. From the sharp jump in the potential indicated by titration curve, the end point could be found out. Mercury nitrate and sodium molybdate were alternately used as titre and the titrant was added by the help of a microburette. $p_{H}$ of the solutions were measured using glass electrode of the range (1 to $\left.13 p_{\mathrm{H}}\right)$ with the help of buffer solutions. 


\begin{tabular}{|c|c|c|c|c|c|}
\hline \multirow[t]{2}{*}{$\begin{array}{l}\text { Molarity of } \\
\mathrm{Na}_{2} \mathrm{MoO}_{4}\end{array}$} & $\begin{array}{c}\text { Molarity of } \\
\mathrm{Hg}\left(\mathrm{NO}_{3}\right)_{2}\end{array}$ & Calculated & \multicolumn{3}{|c|}{$\begin{array}{c}\text { Points of equivalence required for the formation } \\
\text { of } \mathrm{HgO} \cdot \mathrm{MoO}_{3} \text { observed from Max. value of } \\
\Delta E / \Delta V \text { in presence of }\end{array}$} \\
\hline & \multicolumn{2}{|c|}{ Direct Titrations (Fig 1) } & $0 \%$ alcohol & $10 \%$ alcohol & $20 \%$ alcohol \\
\hline $\begin{array}{ll}0.1 & \mathrm{M} \\
0.02 & \mathrm{M}\end{array}$ & $\begin{array}{l}0.0125 \mathrm{M} \\
0.004 \mathrm{M} \\
\text { Reserve }\end{array}$ & $\begin{array}{l}2.50 \mathrm{cc} \\
\quad 4.0 \\
s(\text { Fig } 2)\end{array}$ & $\begin{array}{l}2.40 \text { cc } \\
3.90\end{array}$ & $\begin{array}{l}2.50 \mathrm{cc} \\
3.90\end{array}$ & $\begin{array}{l}2.50 \mathrm{cc} \\
3.90\end{array}$ \\
\hline $\begin{array}{l}0.025 \mathrm{M} \\
0.005 \mathrm{M}\end{array}$ & $\begin{array}{lr}0.2 & \mathrm{M} \\
0.025 \mathrm{M}\end{array}$ & $\begin{array}{l}2.5 \mathrm{cc} \\
4.0\end{array}$ & $\begin{array}{l}2.40 \\
3.90\end{array}$ & $\begin{array}{l}2.45 \\
3.95\end{array}$ & $\begin{array}{l}2.45 \\
3.95\end{array}$ \\
\hline
\end{tabular}

Tab. 1. Summary of the Result of Potentiometric Titrations.

\section{Discussion}

Mercury nitrate was prepared in nitric acid and the $p_{\mathrm{H}}$ was 1.3 of the stock solution. Dilute solutions used in these experiments were of $p_{\mathrm{H}} 2$. The $p_{\mathrm{H}}$ of the $\mathrm{Na}_{2} \mathrm{MoO}_{4}$ was 7.2 and on dilution for experiments it was 7.3. The molybdate ion is said to exist in the following state of aggregation at different $p_{\mathrm{H}}$ of the solution:

$$
\begin{array}{ccc} 
& \mathrm{MoO}_{4}^{--} \rightleftharpoons \mathrm{Mo}_{3} \mathrm{O}_{\overline{11}}^{---} \rightleftharpoons \mathrm{Mo}_{6} \mathrm{O}_{21}^{-----} \\
p \mathrm{H} \quad \text { 14 to 6.5 } & \text { 6.5 to } 4.5 \quad 4.5 \text { to } 1.5
\end{array}
$$

All the above ionic species are $p_{\mathrm{H}}$ reversible. The change from one to another is never sudden, they are supposed to exist in equilibrium. According to Raman

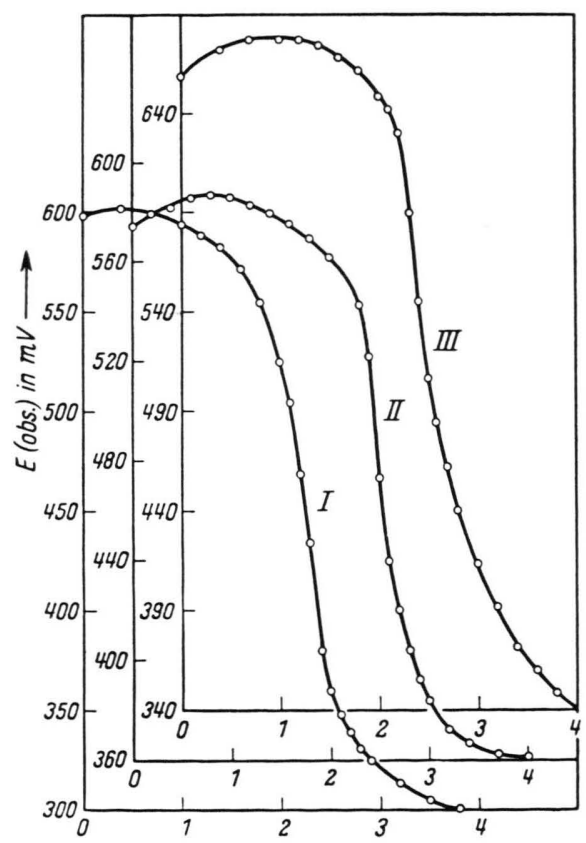

Fig. 1.
$\mathrm{RAO}^{3} \mathrm{Ca}, \mathrm{Ba}, \mathrm{Sr}$ and $\mathrm{Cd}$ are precipitated at $p_{\mathrm{H}} 4.18$ and below this $p_{\mathrm{H}}$, no precipitation takes place. But in this case at $p_{\mathrm{H}} 2$, the normal mercury molybdate is precipitated having the composition $\mathrm{HgO} \cdot \mathrm{MoO}_{3}$. The compound on analysis for the metal and Mo content gave also the same composition as obtained by potentiometric method. It means that solubility product of the mercury molybdate $\mathrm{HgO} \cdot \mathrm{MoO}_{3}$ is low and we are, therefore, of the opinion that normal mercury molybdate $\mathrm{HgO} \cdot \mathrm{MoO}_{3}$ is a very insoluble compound so that very small concentration of $\mathrm{MoO}_{4}{ }^{2} \ominus$, present in highly acidic solutions say $p_{\mathrm{H}} 2$ are sufficient to precipitate the normal mercury molybdate.

The dilution has no effect on the composition of mercury molybdate.

When $\mathrm{Na}_{2} \mathrm{MoO}_{4}$ is added to $\mathrm{Hg}\left(\mathrm{NO}_{3}\right)_{2}$ and reverse,

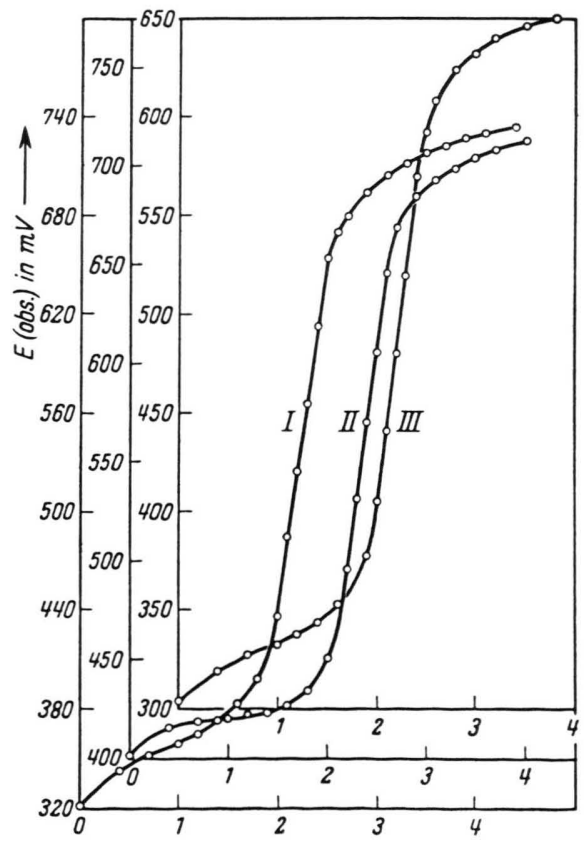

Fig. 2.

${ }^{3}$ D. V. Raman Rao, J. Sci. and Ind. Research 13, 739 [1954]. 
the potential between Platinum indicator electrode and saturated calomel electrode immersed in the solution of the titre is measured and plotted against the volume of the titrant, a sharp jump in potential is observed at the end point, corresponding to the formation and precipitation of normal mercury molybdate $\mathrm{HgO} \cdot \mathrm{MoO}_{3}$. The curves are symmetrical on both sides of the equivalence point and the results are concordant and accurate. The addition of alcohol upto $20 \%$ has, however, no effect on the end point or on the nature of curve. In the vicinity of the end point, the sol begins to coagulate and the equivalence point can be visually detected by the coagulation point of mercury molybdate. The reverse titrations (Fig. 2) give more concordant and accurate results than the direct titrations (Fig. 1). The jump in potential is more marked in the reverse titrations. Reverse titrations can be recommended for the potentiometric estimation of mercury (ic) as mercury molybdate in highly acidic medium ( $p_{\mathrm{H}} 1.4$ to 2 ).

The analytical work on the composition of mercury molybdate is under investigation and the results would be communicated later.

Thanks are due to Dr. S. GHosh, Prof. and Head of the Deptt. of Chemistry, Allahabad University, Allahabad, for his kind help.

\section{BES PRECHUNGEN}

Ciba Foundation Symposium on Paper Electrophoresis. Von G. E. W. Wolstenholme und E. C. P. Millar. Verlag J. \& A. Churchill Ltd. London 1956. IX, 224 S. mit 74 Abb.; Preis geb. 35 s. net.

Wissenschaftler aus aller Welt haben dazu beigetragen, daß die Papier-Elektrophorese in steigendem Maße in der Forschung Anwendung findet. Zur Zeit ist es meist schwierig, die Ergebnisse der einzelnen Schulen und klinischen Laboratorien zu vergleichen, infolge der Verschiedenheit von „Material und Methoden“. Der Zweck dieses Symposiums war es, die Gründe für diese Differenzen zu diskutieren und für die Methodik ohne sie standardisieren zu wollen - eine Basis zu suchen, damit Ergebnisse sich vergleichen lassen. Dieser Versuch muß als fehlgeschlagen angesehen werden, obwohl die Vorträge und die lebhafte Diskussion manche neue Einsichten hervorbrachten.

Was das vorliegende Buch besonders für den Praktiker und auch den Theoretiker der Papier-Elektrophorese so interessant und wertvoll macht, ist die Veröffentlichung der Diskussion; mehr als ein Drittel der Druckseiten wird davon gefüllt. Die Wiedergabe vieler Bilder von Elektropherogrammen und Apparaturen ist ausgezeichnet. Mehrmals fielen uns Irrtümer bei Literaturhinweisen und Bildunterschriften auf. Folgende Vorträge wurden gehalten :

W. Grassmann: Allgemeine Methoden der PapierElektrophorese mit Beispielen ihrer Anwendung auf medizinische und biochemische Probleme. J. DE W AEL: Anwendung der Papier-Elektrophorese zur Differentialdiagnose von Hundekrankheiten. E. M. AbDEL-W V. H. Rees und D. J. R. Laurence: Bestimmung des Albumin-Globulin-Verhältnisses von Blutplasma oder Serum mit der Papier-Elektrophorese. J. C. White, G. H. Beaven und M. Ellis: Analyse von Human-Hämoglobinen mit der Papier-Elektrophorese. Helge Laurell: Eine Papier-elektrophoretische Untersuchung über serumprotein-gebundene Polysaccharide unter dem Einfluß von ACTH und Cortison bei einigen Patienten mit rheumatischer Arthritis, ulcerativer Colitis, usw. E. Körw: Papier-Elektrophorese (Darstellung einer selbstentwickelten Elektrophorese-Apparatur mit einigen Ergebnissen für klinische Diagnostik). H. Svensson: Physikalisch-chemische Aspekte und deren Berücksichtigung bei der Entwicklung von (Elektrophorese-)

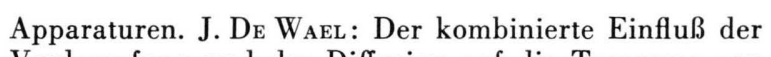
Verdampfung und der Diffusion auf die Trennung von Serumproteinen mittels der Papier-Elektrophorese. E. M. Своок: Analyse von (elektrophoretisch) getrennten Substanzen. H. J. McDonald: Die Flächen unterhalb der "peaks“. S. Chr. Sommerfelt: Einige praktische Winke für die Beurteilung von Papier-Elektrophorese-Streifen. N. H. Martin: Analyse von (elektrophoretisch) getrennten Substanzen. G. Franglen: Einflüsse auf die Proteinfärbung in ihrer Auswirkung auf die Proteinbestimmung mit der Papier-Elektrophorese. H. J. McDonald: Eine neue Methode zur Färbung von Lipoproteinen. E. L. Durrum: Die kommende Entwicklung der (Elektrophorese-) Technik und ihre Anwendung auf die klinische Forschung und die RoutineAnalyse. B. Kickhöfen: Hochspannungs-Papier-Elektrophorese.

G. Werner, Marburg/Lahn.

Seith und Ruthardt, Chemische Spektralanalyse. 5., neu bearbeitete Auflage von W ALter Rollwagen. SpringerVerlag, Berlin 1958. VIII, 162 S. mit 80 Abb.; Preis kart. DM 26.-.

Die in wesentlichen Teilen umgearbeitete, straffer gefaßte und modernisierte Neuauflage läßt den besonderen Charakter des bekannten Buches noch mehr hervortreten: in erster Linie wird auf das Methodische Wert gelegt, auf die Beschreibung und Darstellung der Apparate und ihrer Handhabung mit zahlreichen technischen Einzelheiten. Dagegen treten die theoretischen Grundlagen zurück, ebenso werden Analysenvorschriften nur als Übungsbeispiele gegeben. Vielleicht hätte der überragende Einfluß der Entladungsparameter Stromstärke und Zeitdauer auf den Spektralcharakter noch mehr hervorgehoben werden können. Erwünscht wäre eine Darlegung der Grundsätze bei der Wahl der Bezugselemente und der Bezugslinien. Das Verständnis für diese Zusammenhänge erlaubt auch dem Praktiker einen kleinen Schritt von der empirischen zur bewußt gehandhabten Spektralanalyse. Bemerkt sei noch, daß unter Niederspannungsfunken (S. 23 und 145) jede fremdgezündete Kondensatorentladung zu verstehen ist, während der dargestellte stromstarke Niederspannungsfunke nur eine Unterart bildet. Die Spektralanalytiker werden das Erscheinen der schon lange erwarteten Neuauflage lebhaft begrüßen.

K. Pfeilsticker, Stuttgart. 